\title{
Threat Status of Commercially Exploited Trees in the Nigerian Rainforest
}

\author{
Francis E. Bisong ${ }^{1 *}$, Peter Buckley ${ }^{2}$ \\ ${ }^{1}$ Department of Geography and Environmental Science, University of Calabar, Calabar, Nigeria \\ ${ }^{2}$ Department of Agricultural Sciences, Imperial College, Wye Campus, London, UK \\ Email: febisong@yahoo.com, Peter.buckley@imperial.ac.uk
}

Received 19 August 2014; revised 21 September 2014; accepted 7 October 2014

Copyright (C) 2014 by authors and Scientific Research Publishing Inc.

This work is licensed under the Creative Commons Attribution International License (CC BY).

http://creativecommons.org/licenses/by/4.0/

(c) (i) Open Access

\begin{abstract}
Unregulated commercial-scale exploitation of trees is an indication of the extent of threat to various tree species. The study examined the threat status of commercially exploited trees in the forest estates of South eastern Nigeria. Specifically, it identified tree species under threat, and categorized them into threat classes, as well as determined the rate at which exploited trees were slipping into extinction. The study utilized the IUCN's threat categorization criteria, in determining the threat status of commercially exploited trees. This study combined both secondary and primary data sources generated through Forest Inventory records, Tree Felled Analysis records and Participatory Survey. Data such as population size and density of species, level of exploitation and threat sensitive social and ecological parameters were obtained and applied against the IUCN criteria. Twenty-eight (28) trees species representing Thirty-two percent (32\%) of eighty-six (86) commercially exploited trees were identified as threatened, ranging from the Vulnerable to the Critically Endangered categories. The theory of small and declining population paradigms were found to be of relevance in explaining the processes. Nine tree species such as Triplochiton spp., Baillonella toxisperma, Pogaoleosa, Anopyxis spp. among others were considered to require urgent conservation attention. Recommendations are proposed to halt the process of decline in the biodiversity of exploited trees.
\end{abstract}

\section{Keywords}

Threat status, Commercial, IUCN, Exploited Trees, Endangered, Vulnerable, Threatened Species, Extinction

\section{Introduction}

The speed of loss of natural habitats at global and local levels makes it necessary to acquire information on *Corresponding author. 
which species exist and where they are (Glowka et al., 1994; Thogmartin, 2010). As the number of threatened species increases globally due to wide scale decimation of habitats and ecosystems (Whittaker et al., 2005; Nelson et al., 2010; 5 Eggers et al., 2010; Martorell et al., 2009), the identification and monitoring of species under threat in order to make effective conservation plan becomes critical (Stork et al., 1995; Joseph et al., 2009; Gavin et al., 2010; Underwood et al., 2010).

Plant species in many parts of the world are in danger of extinction. Particularly, target species face harvesting pressure and yet little is known about the threat status of such species to document them on an individual basis (Given, 1994; Joseph et al., 2009). Forests in tropical environments are unstable and hardly maintain fixed climax species composition over long periods. They are victims of modifications by a variety of factors including human influences that result in long lasting disturbances (Bisong, 2004; Bisong et al., 2003; Nicholson et al., 2009; Lawrence et al., 2010; Wade et al., 2010). Forest resource exploitation has progressed in Cross River State in the Niger Delta Region of Nigeria without any specific thought given to the periodic monitoring and evaluation of exploited species, to determine their threats levels.

Analyses of enumeration data of pre-exploitation trees in the forest of Cross River State documented in 1930 (Hall et al., 1977) suggests that $31 \%$ of the species at that time are no longer listed among the exploited species in the region because they have become very rare due to over harvesting (Bisong, 1999; Bisong, 2003). The above underscores the need to identify and monitor tree species under threat from over-exploitation in the region as a basis for developing a conservation and management plan.

The Red Data Books (RDBs) complied by IUCN are a global database of threatened species intended to serve as basis of setting conservation priorities. RDB is based on a quantitative threshold used to categorize species at various levels of threat status. This has been criticized as being too quantitative, with the numerical rankings too specific for the vast number of rare and potentially threatened species (Miller et al., 1995b). In addition, the cost of quantitatively determining species status could constrain most developing countries' ability to protect their wild flora and fauna. Many species are therefore in fact considered threatened but are unlisted because little information exists concerning them (Miller et al., 1995a; Lawrence \& Marshall, 1997). The more critical pattern for local level threat analysis is that the IUCN's criteria may only be appropriately applied for whole taxa at global scales and is unsuitable at national and local levels (Rylands et al., 1995). The need for flexible approaches in determining regional and local estimates of species threat status for national and sub-national territories has therefore become obvious, particularly for prime forest conservation areas. Adapting this criterion to suit regional or county level analysis of threat is also important.

This study integrates a suite of techniques combined with local inventory data and Tree Felled Analysis (TFA) report to determine the threat status of commercially exploited trees in the forest estates of Cross River State. The application of TFA report makes possible the utilization of aspects of IUCN's criteria combined with existing inventory data, aided by computer algorithms to determine threat status for commercially exploited trees of south eastern Nigeria.

\subsection{Objective of Study}

The study therefore examines the threat levels of commercially exploited tree species in the Forest Estates of Cross River State, South-Eastern Nigeria.

The specific objective of this study is to:

1) To identify tree species under threat and categorize according to key factors of threat.

2) To determine the rate at which currently exploited tree species are slipping into extinction and the time it takes for the stock of exploited trees to fall within threat categories.

\subsection{Regional Setting}

Cross River State in the Niger Delta region and South-South Geopolitical zone of Nigeria is a region with the greatest biodiversity concentration in the country. Although occupying just $2.4 \%$ of the of the country's total land surface of $923,850 \mathrm{~km}^{2}$, its national forest covers 924,957 ha (Forest Resources Study, 1999), and represents a sizeable 31\% of the total remaining Tropical Moist Forest in Nigeria (FDD 1994). The area lies between latitude $4^{\circ} 25^{\prime} \mathrm{E}$ and $7^{\circ} 00^{\prime} \mathrm{E}$ and longitude $7^{\circ} 45^{\prime} \mathrm{N}$ and $9^{\circ} 20^{\prime} \mathrm{N}$. The area is considerably diverse with 205 species are endemic to the region, making it one of Africa's biodiversity "hot spots". The region is home to West Africa's only population of western lowland gorillas. Forest Cover Statistics derived from recent satellite images 
for the region show a high rate of forest cover loss. The total deforested area increased by $22.5 \%$ for areas outside the Cross River National Park, between 1991 and 2001, while degraded and fragmented forest increased by an astronomic 522\% (Flasse et al., 2002; Dunn et al., 1994). Much of the cause of forest degradation was of timber exploitation by individuals and concessionaires. Presently, about eighty-six timber species are documented as exploitable species in the region, and much of these without any specific regeneration and conservation plan.

\section{The IUCN's Criteria}

This assigns threat categories hinged on five main criteria, determined by different quantitative thresholds for each category. The criteria include: Population and habitat decline, Habitat area, Population fragmentation or isolation, Population size, and Population viability analysis (PVA). Aspects of the IUCN's Criteria as applicable to the study are provided in the methodology.

While it is acknowledged that calculating extinction risk from the IUCN criteria yields more accurate predications due to its reliance on data based on species number, insufficient information for most taxa is considered a major limitation in applying the approach to regional estimates of extinction rate. (Flasse et al., 2002) asserts that IUCN criteria originally designed to evaluate risk of species extinction at global scales had often produced incorrect assessment when applied to regional subpopulations. The adduced reasons are that sub global population, that is, a continent, country or sub national territory in naturally sub divided biological populations into smaller and restricted sub populations. Since smaller populations have higher extinction risks than larger ones, artificially delineated sub populations may be assessed to have higher risk of extinction than normally would. Regional guidelines have been developed by IUCN to obviate these problems by factoring into the extinction calculus the effect that sub populations outside a region has on the likelihood of extinction in the region being assessed. The guidelines provide for a two phased process and entails: 1) application of IUCN criteria to regional populations as if they are completely isolated, and tentative category assigned; 2) factoring in the effect of populations in neighbouring regions and tentative categories upgraded or downgraded as appropriate (IUCN, 2003). (Given, 1994) however, suggests that threat categories can be applied to entities with reference to any predefined area as large or small as one may desire. A plant may therefore be classed in different threat categories with respect to any area under consideration, such that a species, considered extinct in one place may be endangered in another country and rare in another. The framework provided by IUCN for threat assessment remains the most reliable and robust despite criticism.

\section{Method}

\subsection{Criteria for Determining Threat Status}

Methodology for determining threat status of a taxon was derived from both the IUCN's criteria version 2.3. By applying the IUCN's criteria, species were first listed as Critically Endangered (CR), Endangered (EN), or Vulnerable (VU). The Study utilized IUCN's Criteria-A, C and D for assigning species into threat categories based largely on population reduction considerations.

Criteria A: Species are Critically Endangered if $80 \%$ reduction in population is observed, inferred or suspected to occur over the last 10 years (A1); or if a reduction of $80 \%$, is projected or suspected within the next 10 years (A2). They are considered Endangered if $50 \%$ reduction in population is observed inferred or suspected to occur in past 10 years (A1) or if a reduction of 50\% is projected within the next 10 years (A2). Species are classified as Vulnerable if $20 \%$ reductions have occurred over the last 10 years (A1), or $20 \%$ reduction is projected or suspected to be within the next 10 years (A2). Table 1 outlines the threat levels based on Criteria A.

Criteria C: Species are Critically Endangered if the population is estimated to number less than 250 mature individuals, plus a continuing decline of at least $25 \%$ within three years. Populations are Endangered if they number fewer than 2500 mature individuals, plus showing continuing decline of at least $20 \%$ within 5 years (or two generations). Populations are vulnerable if estimated to number less than 10,000 mature individuals, plus an estimated continuing decline of at least 10 years.

Criteria D: Species are Critically Endangered where the population is estimated to number less than 50 mature individuals. Endangered were population is restricted to less than 250 mature individuals, and Vulnerable where population is restricted to less than 1000 mature individuals.

Each commercially exploited tree species was evaluated against the above-mentioned Criteria (A (1 \& 2), C \& 
Table 1. Criteria for determining species threat status.

\begin{tabular}{|c|c|c|c|}
\hline $\mathrm{S} / \mathrm{n}$ & Threat Category & Description & Criteria \\
\hline \multirow{2}{*}{1} & \multirow{2}{*}{ Critically Endangered (CR) } & $80 \%$ reduction in population observed inferred or suspected to occur over last 10 years & A1 \\
\hline & & $80 \%$ reduction in species population projected to occur within next 10 years & A2 \\
\hline \multirow{2}{*}{2} & \multirow{2}{*}{ Endangered (EN) } & $50 \%$ reduction in population observed inferred or suspected to occur over last 10 years & A1 \\
\hline & & $50 \%$ reduction in species population projected to occur within next 10 years & A2 \\
\hline \multirow{2}{*}{3} & \multirow{2}{*}{ Vulnerable (VU) } & $20 \%$ reduction in population observed inferred or suspected to occur over last 10 years & A1 \\
\hline & & $20 \%$ reduction in species population projected to occur with next 10 years & A2 \\
\hline
\end{tabular}

D) and their Threat category assigned when any of the listed criteria was met, with an indication of the specific criterion. “All taxa listed as Critically Endangered qualify for Vulnerable and Endangered, and all listed as Endangered qualify for vulnerable. They are all regarded as threatened”.

The population size of a species is used in reference to the number of mature individuals only, while in turn refers to the numbers known, estimated or inferred to be capable of reproduction. In the context of this study, mature trees are those with a diameter at breast high $(\mathrm{DBH})>90 \mathrm{~cm}$. Population reductions are expressed as the percentage decline in the number of mature individuals within the amount (\%) stated time frame, while continuing decline is a recent, current or projected future decline from unknown cause or causes not adequately controlled, and liable to continue except when mitigation measures are adopted (Miller et al., 1995a; Barbault et al., 1995; Chittaro et al., 2010; Deb et al., 2011; Frankel et al., 1998).

\subsection{Data Source/Collection Methods}

The data set used to evaluate the species against the IUCN's criteria are the actual/projected levels of tree species exploitation, the population size and density of the species (relating to their abundance), the habitat defining species range, and the level of change in species stocking. Population size estimates of species were derived from the density per hectare of mature tree stands multiplied by the size of total habitat area derived from forest inventory data of Cross River State (Dunn et al. 1994).

The actual level of species exploitation was derived from the Tree Felled Analysis data, which reports monthly the number and volume $\left(\mathrm{m}^{3}\right)$ of timber trees felled by species type across the ecological zones in the study region from 1990 to 2004. Apart from showing change in the magnitude to which species are being exploited, it helps forecast future exploitation, which consequently highlights the rate at which the stock of exploited trees is tending towards extinction. Variables such as geographic range, population size, density, exploitation pressure and reproductive success were derived from the Inventory and Tree Felled Analysis data. Reproductive success of the tree species was estimated from density per hectare of juvenile trees $(10 \mathrm{~cm}-29 \mathrm{~cm}$ dbh) (Dunn et al. 1994).

\subsection{Sampling}

The Inventory data was restricted to trees larger than $10 \mathrm{~cm}$ diameter on systematically laid down 2 ha Temporary Sample Plot (PSP) at the corner of every block of $20 \mathrm{~km}^{2}$. A total of 130 plots were sampled, 118 plots in the high forest, and 12 plots in the swamp forest (Forest Resources Study, 1999). Tree Felled Analysis data reports include felled trees by species type, number, and volume $\left(\mathrm{m}^{3}\right)$ from 23 forest charges and sub-charges across all major ecozones and covering all forestry estates in the study region outside the Cross River National park. They were again re-organized into ecozones based on geography and the bioclimatic characteristics of the region.

\subsection{Data Analysis}

The first step in the data analysis chain is a linear trend analysis of the exploitation data (Tree Felled Analysis) to determine the level to which the present population of trees stocking may reduce over stipulated time frame proposed by IUCN Criteria A2 and C. To assign threat category on the basis of IUCN criteria for A1 and D, the total number of trees felled over the last ten years was deducted from the population size of trees at the base year to determine whether the percentage reduction met with IUCN criteria for the category. 
The threat status for the tax on was thus determined on IUCN's Criteria A (1 \& 2), C and D. The data sets were subjected to various kinds of arithmetic manipulations using (Microsoft Excel). Various algorithms were thus written on the spreadsheet cells on the basis of the logic provided by the IUCN criteria, which determined species threat category on the basis of projected population reduction estimates (Criteria A2 and C) and previous exploitation levels (Criteria A1 and D).

The Algorithms applied a series of arithmetic manipulations to the data set operationalized by the use of "AND" and "OR" spreadsheet functions using Microsoft Excel Software in a complex nested logical algorithms to identify data that met the IUCN Criteria

\subsection{Arithmetic Procedures for Criteria A (1 \& 2)}

To determine species threat category hinged on Criteria A1 on the basis of population reduction estimates for previous exploitation (see Table 1), the following arithmetic manipulations were applied to the data set dealing with exploitation records between 1990 and 2004. The procedures entailed a sum of the yearly value of number of trees felled or exploited within last 10 years i.e. from 1995 to 2004.

Red 10 yrs\% = Exploitation between 1995 and 2004×100 / Pop 95 = Red 10yrs / Pop95

where:

Red $10 \mathrm{yrs} \%=$ Percentage reduction in the population of trees exploited in past 10 years

Red 10 yrs (reduction over past 10 years) = Pop 95 - Pop 2004

Pop 95 = Pop $1990-$ Pop 95 (Base year Population at 1990 - Sum of exploitation up to 1995)

Pop $90=$ base year population of trees in 1990

Pop 2004 = base year population - Sum of exploitation up to 2004

For the species threat category using Criterion A2, based on a projected reduction strategy in the population of species to occur within the next ten years (Table 1). A sum up of the yearly value of trees projected or suspected to be exploited from 2005 up to 2015 was made. The arithmetic procedures include:

$$
\begin{aligned}
& \text { Projected Population = Pop 2005- Pop } 2015 \\
& \text { Base Year = Base Yr Pop (1990) }- \text { Exploitation Base Year } 2015 \\
& \text { Pop } 2005 \text { = Already Known } \\
& \text { Projected Reduction = Pop 2005- Pop } 2015 \\
& \text { Projected (\%) Reduction = Projected / Pop 2005×100 }
\end{aligned}
$$

The output of trend analysis and population reduction estimates based on IUCN Criteria A1 \& 2 and C applied on the tree species population and level of exploitation data reduces the bewildering list of commercially exploited tree species to a revised of the most threatened species, as well as providing vital information for conservation planning.

The list of threatened species (Vulnerable to Critically Endangered on the IUCN's criteria) was rescored for a range of factors such as geographic range, commercial value, social utility, keystone characteristics, threat status and taxonomic distinctiveness to determine their conservation priority rating. These scores were summed and to a percentage index score to give an overall as well as group rating in order to guide conservation planning of exploited tree species in the region. Species scoring $\geq 60 \%$ on the overall scale were accorded high conservation priority status.

\section{Result}

\subsection{Threat Status of Commercially Exploited Trees of Cross River State}

Criteria A (1 \& 2)

IUCN Criteria A (1 \& 2) were based on a population reduction estimates of species from previous exploitation in past ten years (A1) and projected decline in species population within next ten years (A2). To determine species threat status on the basis of these criteria, exploitation records (1990-2004) of eighty-six (86) commercially exploited trees were obtained from the Cross River State Forestry Commission. From these records, projected 
levels of future exploitation (2005-2015) were derived. Both past and projected levels in the population of trees exploited.

The algorithms provided in the method section based on IUCN Criteria A1 \& 2 were applied to the data sets. The results obtained. The species that met the critical value for threat category with respect to IUCN's Criteria A1 \& 2, namely "Critically Endangered" (CR), "Endangered" (EN) and "Vulnerable" (VU) are shown in Table 2.

The table information reveals that twenty-eight tree species, representing 32 percent of the eighty-six commercially exploited timber species in Cross River State are threatened. On the basis of A1 Criteria, 8 percent (7) of these species are Critically Endangered with greater than $80 \%$ reduction in their population in past 10 years, 3 percent (3) are Endangered with 50 to $<80 \%$ reduction in their population in last 10 years, and 13 percent (11) are Vulnerable having experienced between 20 to $<50 \%$ reduction in their population. Based on Criterion A2 however, 19 percent (16) of these species are "Critically Endangered" having been projected to decline by $>80 \%$ in their population within the next 10 years, 2 percent (2) are Endangered with a projected reduction of between 50 to $<80 \%$ within the next 10 years, and 12 percent (14) are Vulnerable being anticipated to face between 20 to $<50 \%$ reduction in their population within the next 10 years. It is important to note that many species listed as Critically Endangered (i.e. estimated to have suffered or projected to suffer between $80 \%-90 \%$ reduction in past or future population stocks) do in fact face near extinction possibilities as they are listed to suffer population decline far in excess of IUCN's threshold of $90 \%$. The algorithms used assigned species with $\geq 90 \%$ reduction in past or projected population to threat category of "Near Extinct". All such are however numbered as Critically Endangered.

In Table 3 a few worked examples are presented to show how the criteria for estimating threats were applied. The arithmetic manipulations used to determine past (10 yrs) and future (10 yrs) estimates of reduction in species population are provided in the Table footnote.

The critical columns in the table are:

1) Red 10yrs 1995 to 2007 (7) = Reduction in past ten year from 1995 to 2005

2) Red 10 yrs 2005 to 2015 (g) = Reduction projected for next ten years from 2005 to 2015

3) Past Red\% (9) $=\%$ of past reduction (past 10 years)

4) Proj Red\% $=\%$ projected Reduction (next 10 years)

1) Red_10 yrs_95 to 2005 (7) = Reduction in past ten years from 1995 to 2005.

2) Red_10 yrs_2005 to 2015 (8) = Reduction projected for next ten years from 2005 to 2015.

3) Past_Red\% (9) = \% of past reduction (past 10 years).

4) Proj_Red\% (10) = \% of Projected Reduction (next 10 years).

The percentage population reduction estimates given in columns 9 and 10 of the table provides the guide to assigning threat category to species on the basis of IUCN's Criteria A1 and A2 respectively. Using Table 1 information as framework, species are thus assigned to their threat classes as shown in columns 11 and 12 of Table 3.

Table information clearly shows that Afzelia, the first listed species is for example endangered on Criteria A2 as $52 \%$ of its population is projected to decline within the next ten years (i.e. 2005 to 2015). It is however vulnerable on criteria A1 having experienced $22 \%$ reduction in its population in past 10 years.

Further highlight from Table 3 reveals that four of the species, namely, Amphimas spp.; Alstonia spp.; Berlinea confusa and Brachystegia spp. are listed as not threatened as they fall short of any of the IUCN criteria set on the basis of population reduction (A1 \& 2), while six of the species come under various threat categories from the Critically Endangered and or Near Extinction possibilities (Criterion A2), as for Anopyxis and Bombax spp. respectively, to Endangered (Criterion A2) for Afzelia and Baillonella species, and Vulnerable on (Criteria A1 \& 2) as in Antiaris africana and Araliopsisso yauxil.

\subsection{Threat Status of Species on Criteria C and D}

Criterion $\mathrm{C}$ is built around species attaining specific population thresholds or minima plus a continued decline in a given proportion of the population over specific time frames (see Method). The application of the algorithms on Criterion D is on the other hand simply straight-forward with species, considered "Critically Endangered", "Endangered" and "Vulnerable" if present population is estimated to number less than 50,250 and 1000 mature individuals respectively. 
Table 2. Threatened plants and threat status of commercially exploited trees in Cross River State (IUCN Criteria A1 \& 2).

\begin{tabular}{|c|c|c|c|c|c|}
\hline $\mathrm{S} / \mathrm{N}$ & Species & $\begin{array}{c}\text { Past_Red\% } \\
\text { (Past } 10 \text { Yrs) A1 }\end{array}$ & $\begin{array}{c}\text { Proj_Red\% } \\
\text { (Next } 10 \text { Yrs) A2 }\end{array}$ & Threat Status on A1 & Threat Status on A2 \\
\hline 1 & Afzelia spp. & $22 \%$ & $52 \%$ & Vulnerable & Endangered \\
\hline 2 & Anopyxis spp. & $35 \%$ & $82 \%$ & Vulnerable & Critically Endangered \\
\hline 3 & Antiaris africana & $14 \%$ & $26 \%$ & No Threat & Vulnerable \\
\hline 4 & Araliopsis soyauxil & $26 \%$ & $23 \%$ & Vulnerable & Vulnerable \\
\hline 5 & Baillonealla spp. & $22 \%$ & $56 \%$ & Vulnerable & Endangered \\
\hline 6 & Baphia spp. & $7 \%$ & $38 \%$ & No Threat & Vulnerable \\
\hline 7 & Bombax spp. & $42 \%$ & $227 \%$ & Vulnerable & Near Extinct (CR) \\
\hline 8 & Diospyros spp. & $325 \%$ & $-167 \%$ & Near Extinct (CR) & Near Extinct (CR) \\
\hline 9 & Drypetes spp. & $70 \%$ & $141 \%$ & Endangered & Near Extinct (CR) \\
\hline 10 & Entandrophragma spp. & $89 \%$ & $1541 \%$ & Critically Endangered & Near Extinct (CR) \\
\hline 11 & Guarea thompsonii & $90 \%$ & $1297 \%$ & Critically Endangered & Near Extinct (CR) \\
\hline 12 & Khaya ivorensis & $48 \%$ & $432 \%$ & Vulnerable & Near Extinct (CR) \\
\hline 13 & Lannea spp. & $11 \%$ & $21 \%$ & No Threat & Vulnerable \\
\hline 14 & Lophira lanceolata & $44 \%$ & $120 \%$ & Vulnerable & Near Extinct (CR) \\
\hline 15 & Lovoa trichilioides & $784 \%$ & $-187 \%$ & Near Extinct (CR) & Near Extinct (CR) \\
\hline 16 & Mammea africana & $25 \%$ & $28 \%$ & Vulnerable & Vulnerable \\
\hline 17 & Milicia excels & $31 \%$ & $101 \%$ & Vulnerable & Near Extinct (CR) \\
\hline 18 & Mitragyna spp. & $131 \%$ & $-394 \%$ & Near Extinct (CR) & Near Extinct (CR) \\
\hline 19 & Nauclea spp. & $16 \%$ & $32 \%$ & No Threat & Vulnerable \\
\hline 20 & Oxystigma manii & $150 \%$ & $-665 \%$ & Near Extinct (CR) & Near Extinct (CR) \\
\hline 21 & Parinari spp. & $17 \%$ & $28 \%$ & No Threat & Vulnerable \\
\hline 22 & Piptadeniastrum spp. & $13 \%$ & $21 \%$ & No Threat & Vulnerable \\
\hline 23 & Poga oleosa & $32 \%$ & $40 \%$ & Vulnerable & Vulnerable \\
\hline 24 & Pterygota spp. & $66 \%$ & $222 \%$ & Endangered & Near Extinct (CR) \\
\hline 25 & Staudtia stipitata & $2446 \%$ & $-101 \%$ & Near Extinct (CR) & Near Extinct (CR) \\
\hline 26 & Sterculia oblongata & $13 \%$ & $30 \%$ & No Threat & Vulnerable \\
\hline 27 & Symphonia spp. & $52 \%$ & $99 \%$ & Endangered & Critically Endangered \\
\hline 28 & Triplochiton spp. & $39 \%$ & $104 \%$ & Vulnerable & Near Extinct (CR) \\
\hline
\end{tabular}

Key: Past_Red\%=\% Past reduction; Proj_red\%=\% of projected reduction. Source: Author’s Computation.

The arithmetic manipulations and algorithms designed for Criteria C and D (see method section) were applied to the data set to determine species threatened under Criterion C. The result shows that only three species Khaya ivorensis, Lovoa trichiliodes and Oxystigma manii attained various threat categories on Criterion C, while thirteen (13) species attained threat conditions on Criterion D.

A careful observation of the data reveals that Khaya spp. might attain a Critically Endangered threat status on Criterion C between 2012 and 2015 where it would have attained a continued decline of no less than 25\% in its population within 3 years (CD3 column), in addition to having been reduced to a population size of less than 250 individuals (present population column). Similarly, Lovoa spp. will be Critically Endangered between 2003 and 2005, while Oxystigma spp. would have attained a Critically Endangered status between 2012 and 2015.

The Thirteen (13) species threatened on IUCN's criteria D are shown in Table 4. Five of these species are Critically Endangered, with present population sizes numbering less than 50 mature individuals, Two (2) are Endangered with population sizes estimated to number less than 250 mature individuals, while (5) are vulnerable with population numbering less than 1000 mature individuals. The list of all threatened species with respect to all criteria utilized on the IUCN scale is shown in Table 5.

Table 5 clearly shows that of the twenty eight (28) threatened species, all are confirmed to be threatened in one or more of the threat category on Criterion A2, twenty one (21) attained threat status on Criteria A1, three (3) 
Table 3. Estimating threats for selected species on Criteria A1 \& 2.

\begin{tabular}{|c|c|c|c|c|c|c|c|c|c|c|c|c|}
\hline & 1 & 2 & 3 & 4 & 5 & 6 & 7 & 8 & 9 & 10 & 11 & 12 \\
\hline Species & $\begin{array}{c}\text { Exp_B } \\
\text { Y to } \\
95\end{array}$ & $\begin{array}{l}\text { Exp_BY } \\
\text { to } 2005\end{array}$ & $\begin{array}{l}\text { Exp_BY } \\
\text { to } 2015\end{array}$ & $\begin{array}{c}\text { Pop } \\
95\end{array}$ & $\begin{array}{l}\text { Pop } \\
2005\end{array}$ & $\begin{array}{l}\text { Pop } \\
2015\end{array}$ & $\begin{array}{l}\text { Red_10 } \\
\text { yrs_95 to } \\
2005\end{array}$ & $\begin{array}{l}\text { Red_10 yrs_ } \\
2005 \text { to } 2015\end{array}$ & $\begin{array}{l}\text { Past_ } \\
\text { Red\% }\end{array}$ & $\begin{array}{l}\text { Proj_ }_{-} \\
\text {red\% }\end{array}$ & $\begin{array}{c}\text { Threat Status } \\
\text { A1 (Past } 10 \\
\text { Yrs) }\end{array}$ & $\begin{array}{c}\text { Threat Status A2 } \\
\text { (Next } 10 \text { Yrs) }\end{array}$ \\
\hline Afzelia spp. & 150 & 2900 & 7890 & 12367 & 9617 & 4628 & 2750 & 4990 & $22 \%$ & $52 \%$ & Vulnerable & Endangered \\
\hline $\begin{array}{l}\text { Amphimas } \\
\text { spp. }\end{array}$ & 440 & 1964 & 3968 & 33159 & 31635 & 29631 & 1524 & 2004 & $5 \%$ & $6 \%$ & No Threat & No Threat \\
\hline $\begin{array}{l}\text { Antiaris } \\
\text { africana }\end{array}$ & 90 & 1652 & 4133 & 11110 & 9548 & 7067 & 1562 & 2481 & $14 \%$ & $26 \%$ & No Threat & Vulnerable \\
\hline Alstonia spp. & 90 & 880 & 2551 & 11110 & 10320 & 8648 & 790 & 1671 & $7 \%$ & $16 \%$ & No Threat & No Threat \\
\hline $\begin{array}{c}\text { Araliopsis } \\
\text { soyauxil }\end{array}$ & 212 & 846 & 1252 & 2423 & 1789 & 1383 & 634 & 406 & $26 \%$ & $23 \%$ & Vulnerable & Vulnerable \\
\hline $\begin{array}{l}\text { Anopyxis } \\
\text { spp. }\end{array}$ & 94 & 528 & 1175 & 1224 & 790 & 143 & 434 & 647 & $35 \%$ & $82 \%$ & Vulnerable & $\begin{array}{l}\text { Critically } \\
\text { Endangered }\end{array}$ \\
\hline $\begin{array}{l}\text { Baillonealla } \\
\text { spp. }\end{array}$ & 610 & 3246 & 8456 & 11907 & 9271 & 4061 & 2636 & 5210 & $22 \%$ & $56 \%$ & Vulnerable & Endangered \\
\hline $\begin{array}{l}\text { Berlinea } \\
\text { confusa }\end{array}$ & 144 & 900 & 2415 & 24890 & 24134 & 22619 & 756 & 1515 & $3 \%$ & $6 \%$ & No Threat & No Threat \\
\hline Bombax spp. & 54 & 1812 & 7421 & 4228 & 2470 & -3139 & 1758 & 5609 & $42 \%$ & $227 \%$ & Vulnerable & Near Extinct \\
\hline $\begin{array}{c}\text { Brachystegia } \\
\text { spp. }\end{array}$ & 4126 & 12516 & 22477 & 223489 & 215099 & 205138 & 8390 & 9961 & $4 \%$ & $5 \%$ & No Threat & No Threat \\
\hline
\end{tabular}

Key: Exp_By to 95 = Exploitation from Base Year to 1995; Exp_By to 2005 = Exploitation from Base Year to 2005; Exp_By to 2015 = Exploitation from Base Year to 2015; Pop 2005 = Population at 1995; Pop 2005 = Population at 2005; Pop $2015=$ Population 1 t 2015 . Red 10 yrs 95 to 2005 = Reduction in Past Ten Year From 2005 to 2015; \% Past_Red = \% of Past Reduction; \% Projected = \% of Projected Reduction. Source: Author's Computation.

Table 4. Threatened species using IUCN Criterion D.

\begin{tabular}{ccccccc}
\hline S/n & Species & Base Year Pop (1990) & qty Exploited & Exploitation to Date & Present Population (2005) & Threat Status D \\
\hline 1 & Anopyxis spp. & 1317.6 & 54 & 528 & 790 & Vulnerable \\
2 & Diospyros spp. & 1317.6 & 195 & 2567 & Critical \\
3 & Drypetes spp. & 800 & 36 & 623 & 1249 & Endangered \\
4 & Entandrophragma spp. & 6917.4 & 766 & 6294 & 623 & 106 \\
5 & Guarea thompsonii & 1317.6 & 117 & 1212 & 669 & -3184 \\
6 & Lophira lanceolata & 1317.6 & 67 & 649 & -248 & Vulnerable \\
7 & Lovoa trichilioides & 1317.6 & 490 & 4502 & Critical \\
8 & Mitragyna spp. & 1317.6 & 100 & 1566 & Critical \\
9 & Oxystigma manii & 1317.6 & 227 & 1781 & Critical \\
10 & Pterygota spp. & 1317.6 & 74 & 958 & 360 \\
11 & Staudtia stipitata & 1317.6 & 272 & 4030 & -2712 \\
12 & Symphonia spp. & 1317.6 & 24 & 758 & Vulnerable \\
13 & Triplochiton spp. & 1317.6 & 62 & 598 & Critical \\
\hline
\end{tabular}

Source: Author's Computation.

were threatened on Criterion C, and thirteen (13) on Criterion D. Criterion A2 is from the above evidently more robust as a threat predictor via a population reduction strategy on the IUCN's criteria.

\section{Discussion}

Analysis of information in Table 2 reveals that species threat status fulfils at least three (A, C and D) of the IUCN criteria of threatened species, one of which is sufficient to ensure a listing in the threat category. While Criteria A1 highlights vulnerability to be predicated on a significant reduction in the population of species within the last 10 years, Criteria A2 forecasts or projects significant reduction in species population within the next 10 
Table 5. Threatened plants and threat status of commercially exploited trees in Cross-River State (for IUCN's Criteria A1 \& 2) C \& D.

\begin{tabular}{|c|c|c|c|c|c|}
\hline $\mathrm{S} / \mathrm{N}$ & Species & Threat Status on A1 & Threat Status on A2 & Threat Status on D & Threat Status on D \\
\hline 1 & Afzelia spp. & Vulnerable & Endangered & - & Vulnerable \\
\hline 2 & Anopyxis spp. & Vulnerable & Critically Endangered & - & - \\
\hline 3 & Antiaris africana & - & Vulnerable & - & - \\
\hline 4 & Araliopsis soyauxil & Vulnerable & Vulnerable & - & - \\
\hline 5 & Baillonealla spp. & Vulnerable & Endangered & - & - \\
\hline 6 & Baphia spp. & - & Vulnerable & - & - \\
\hline 7 & Bombax spp. & Vulnerable & Near Extinct (CR) & - & - \\
\hline 8 & Diospyros spp. & Near Extinct (CR) & Near Extinct (CR) & - & - \\
\hline 9 & Drypetes spp. & Endangered & Near Extinct (CR) & - & Endangered \\
\hline 10 & Entandrophragma spp. & Critically Endangered & Near Extinct (CR) & - & Vulnerable \\
\hline 11 & Guarea thompsonii & Critically Endangered & Near Extinct (CR) & - & Endangered \\
\hline 12 & Khaya ivorensis & Vulnerable & Near Extinct (CR) & Critically Endangered & - \\
\hline 13 & Lannea spp. & - & Vulnerable & - & - \\
\hline 14 & Lophira lanceolata & Vulnerable & Near Extinct (CR) & - & Vulnerable \\
\hline 15 & Lovoa trichilioides & Near Extinct (CR) & Near Extinct (CR) & Critically Endangered & Critically Endangered \\
\hline 16 & Mammea aficana & Vulnerable & Vulnerable & - & - \\
\hline 17 & Milicia excels & Vulnerable & Near Extinct (CR) & - & - \\
\hline 18 & Mitragyna spp. & Near Extinct (CR) & Near Extinct (CR) & - & Critically Endangered \\
\hline 19 & Nauclea spp. & - & Vulnerable & - & - \\
\hline 20 & Oxystigma manii & Near Extinct (CR) & Near Extinct (CR) & Critically Endangered & Critically Endangered \\
\hline 21 & Parinari spp. & - & Vulnerable & - & - \\
\hline 22 & Piptadeniastrum spp. & - & Vulnerable & - & - \\
\hline 23 & Poga oleosa & Vulnerable & Vulnerable & - & - \\
\hline 24 & Pterygota spp. & Endangered & Near Extinct (CR) & - & Vulnerable \\
\hline 25 & Staudtia stipitata & Near Extinct (CR) & Near Extinct (CR) & - & Critically Endangered \\
\hline 26 & Sterculia oblongata & - & Vulnerable & - & - \\
\hline 27 & Symphonia spp. & Endangered & Critically Endangered & - & Vulnerable \\
\hline 28 & Triplochiton spp. & Vulnerable & Near Extinct (CR) & - & Vulnerable \\
\hline
\end{tabular}

Key: “-” means no threat under given criteria; Source: Author’s Computation.

years to warrant categorization into a threat class.

The fulfilment of Criteria C and D on the other hand is established on the basis of the threshold size of species population. The fulfilment of the indicated criteria in the establishment of threat categories justifies the relevance and applicability of the theory of small and declining population paradigms in highlighting species threat status. Criteria A1 and A2 give a powerful indicator of the cause of smallness as expounded by the declining population paradigm. In this case, the excessive rate of species exploitation beyond replaceable limits is the major cause of biodiversity decline in trees species population in Cross River State. Twelve out of twenty-eight species fulfilling criteria A2 (see Table 2), for instance, show the rate of decline projected to occur within the next 10 year to be far in excess of $100 \%$, clearly signalling likely hood of extinction within the given time frame if present exploitation rate continues.

The fulfilment of Criteria $\mathrm{C}$ and $\mathrm{D}$ clearly implies that processes that the effects of smallness will begin to operate on the persistence of a population unless strong mitigation measures are introduced. Six of the eight species in the high threat category were listed as critically Endangered and/or facing Near Extinction possibilities in the IUCN criteria. The IUCN's criteria on population reduction do help to pinpoint the rate at which species are slipping into extinction. It could also come handy as a fallback threat estimator where vital population data of species are unavailable. Its strongest point remains its multidimensional approach to species threat assessment as well as its being amenable to both qualitative and quantitatively derived data. 


\section{Conclusion \& Recommendations}

The conclusion to be made from the above is that a great number of the commercially exploited timber species are slipping into extinction due to over-harvesting. The most vulnerable species with respect to extinction possibilities have been indicated. Strong mitigative measures are required to halt the process of decline in the number of commercially exploited trees. The information presented and analysis made could serve as a frame of reference to guide a proper assessment of the situation by the authorities responsible for forest management and conservation. Urgent steps must be taken to protect the most vulnerable species in accordance with biological and socio-economic imperatives.

\section{References}

Barbault, R., \& Sastrapradjo, S. (1995). Generation, Maintenance and Loss of Biodiversity. In V. H. Heywood, \& R. T. Watson (Eds.), Global Biodiversity Assessment (pp. 201-274). New York: Cambridge University Press.

Bisong, F. E., \& Arokoyu, S. B. (2003). Agricultural Land Use Modelling and Deforestation: An Analysis of Proximate Drivers in South-Eastern Nigeria. Ghana Educational Media and Technology Association Journal, 5, 47-64.

Bisong, F. E. (2003). Deforestation Motivators by Small Farmers in Common and Protected Lands in South-Eastern Nigeria: A Factor Analytical Approach. Mathematics Connection, 3, 1-23.

Bisong, F. E. (2004). Population Deforestation and Biodiversity Erosion in the Context of Rural Agricultural Extenesion in South Eastern Nigeria. African Journal of Educational Studies in Mathematics and Sciences, 2, 91-105.

Bisong, F. E. (1999). Deforestation and the Erosion of Biodiversity in the Cross River State Rainforest, South Eastern Nigeria. Global Journal of Pure and Applied Science, 5, 241-250.

Chittaro, P., Kaplan, I., Kehler, A., \& Levin, P. (2010). Trade-Offs between Species Conservation and the Size of Marine Protected Areas. Conservation Biology, 24, 197-206. http://dx.doi.org/10.1111/j.1523-1739.2009.01323.x

Deb, P., \& Sundriyal, R. (2011). Vegetation dynamics of an old growth lowland tropical rainforest in North-East India: species composition and stand heterogeneity. International Journal of Biodiversity and Conservation, 3, 405-430,

Dunn, R. M., Otut, D. U., \& Wong, J. L. G. (1994). Report of the Reconnaissance Inventory of High Forest and Swamp Forest Areas in Cross River State, Nigeria.

Eggers, B., Matern, A., Drees, C., Egger, J., Harattle, W., \& Assmann, T. (2010). Value of Semi-Open Corridors for Simultaneous Connecting Open and Wooded Habitats: A Case Study with grand Beetles. Conservation Biology, 24, 256-266. http://dx.doi.org/10.1111/j.1523-1739.2009.01295.x

FDD (1994). A Strategy for Sustainable Conservation and Management of the Forest of Cross River State. Forestry Development Department, Cross River State, Calabar.

Flasse, S., Archer, D., Boschetti, L., \& Abell, T. (2002). Rapid Appraisal of Forest Resources from Remotely Sensed Data in Cross River State, Nigeria. Final Report. CRSCFP, ERM \& DFID.

Forest Resources Study (1999). NIGERIA: Cross River State, National Report Volume 1. FORMECU, Nigeria: Federal Department of Forestry.

Frankel, O. H., Brown, A. H., \& Burdon, J. J. (1998). The Conservation of Plant Biodiversity. Cambridge: Cambridge University Press, p. 222.

Gavin, M. C., Solomon, J. N., \& Blank, S. G. (2010). Measuring and Monitoring Illegal Use of Natural Resources. Conservation Biology, 24, 89-100.

Given, D. R. (1994). Principles and Practice of Plant Conservation. London: Chapman \& Hall, 37-83.

Glowka, L., Burhenne-Guilmin, F., Synge, H., McNeely, J. A., \& Gundling, L. (1994). A Guide to the Conservation on Biological Diversity. Environmental Policy and Law Report No. 30, IUCN: The World Conservation Union.

Hall, B. J. (1977). Forest-Types in Nigeria: An Analysis of Pre-Exploitation Forest Enumeration Data. Journal of Ecology, 65, 187-199. http://dx.doi.org/10.2307/2259073

Joseph, L., Maloney, R., \& Possingham, H. (2009). Optimal Allocation of Resources among Threatened Species: A Project Priotization Protocol. Conservation Biology, 23, 328-338. http://dx.doi.org/10.1111/j.1523-1739.2008.01124.X

Lawrence, M. J., \& Marshall, D. F. (1997). Plant Population Genetics. In N. Maxted, B. V. Ford-Lloud, \& J. G. Hawkes (Eds.), Plant Genetic Conservation: The in Situ Approach (pp. 99-113). London: Chapman \& Hall.

Lawrence, A., Afifi, R., Ahmed, A., Khahfa, S., \& Paget, T. (2010). Bioactivity as an Options Value of Sea Cucombers in the Egyptian Red Sea. Conservation Biology, 24, 217-225. http://dx.doi.org/10.1111/j.1523-1739.2009.01294.X

Martorell, C., \& Peters, E. (2009). Disturbance Response Analysis: A Method for Rapid Disturbed Areas. Conservation Biology, 23, 377-387. http://dx.doi.org/10.1111/j.1523-1739.2008.01134.x 
Miller, K., Allegretti, M. H., Johnson, N., \& Johsson, B. (1995a). Sustainable Use of Its Components. In V. H. Heywood (Ed.), Global Biodiversity Assessment UNEP. Cambridge: Cambridge University Press.

Miller, K., Allegretti, M. H., Johnson, N., \& Johsson, B. (1995b). Measures for Conservation of Biodiversity and Sustainable Use of Its Components. In V. H. Heywood, \& R. T. Watson (Eds.), Global Biodiversity Assessment. Cambridge: Cambridge University Press.

Nelson, F., Foley, C., Foley, L., Leposo, A., Loore, E., Peterson, D. et al. (2010). Payments for Ecosystem Services as Framework for Community-Based Conservation in Northern Tanzania. Conservation Biology, 24, 78-85. http://dx.doi.org/10.1111/j.1523-1739.2009.01393.x

Nicholson, E., Keith, D., \& Wilove, D. (2009). Assessing the Threat Status of Ecological Communities. Conservation Biology, 23, 259-274. http://dx.doi.org/10.1111/j.1523-1739.2008.01158.x

Rylands, A., \& Luna, E. R. (1995). A New System for Classifying Threatened Status. Neotropical Primates, 3, 109-112.

Stork, N. E., \& Samways, M. J. (1995). Inventorying and Monitoring. In V. H. Heywood (Ed.), Global Biodiversity Assessment UNEP. Cambridge: Cambridge University Press.

Thogmartin, W. E. (2010). Modeling and Mapping Golden-Winged Warbler Abundance to Improve Regional Conservation Strategies. Avian Conservation and Ecology, 5, 12. http://dx.doi.org/10.5751/ACE-00426-050212

Underwood, J., D’Agrosa, C., \& Gerber, L. (2010). Identifying Conservation Areas on the Basis of Alternative Distribution Datasets. Conservation Biology, 24, 162-120. http://dx.doi.org/10.1111/j.1523-1739.2009.01303.x

Wade, A., \& Theobald, D. (2010). Residential Development Encroachment on U.S. Protected Areas. Conservation Biology, 24, 151-161. http://dx.doi.org/10.1111/j.1523-1739.2009.01296.x

Whittaker, R., Miguel, B., Araújo, M., Jepson, P., Ladle, R., Watson, J., \& Willis, K. (2005). Conservation Biogeography: Assessment and Prospect. Diversity and Distributions, 11, 3-23. http://dx.doi.org/10.1111/j.1366-9516.2005.00143.X 
Scientific Research Publishing (SCIRP) is one of the largest Open Access journal publishers. It is currently publishing more than 200 open access, online, peer-reviewed journals covering a wide range of academic disciplines. SCIRP serves the worldwide academic communities and contributes to the progress and application of science with its publication.

Other selected journals from SCIRP are listed as below. Submit your manuscript to us via either submit@scirp.org or Online Submission Portal.
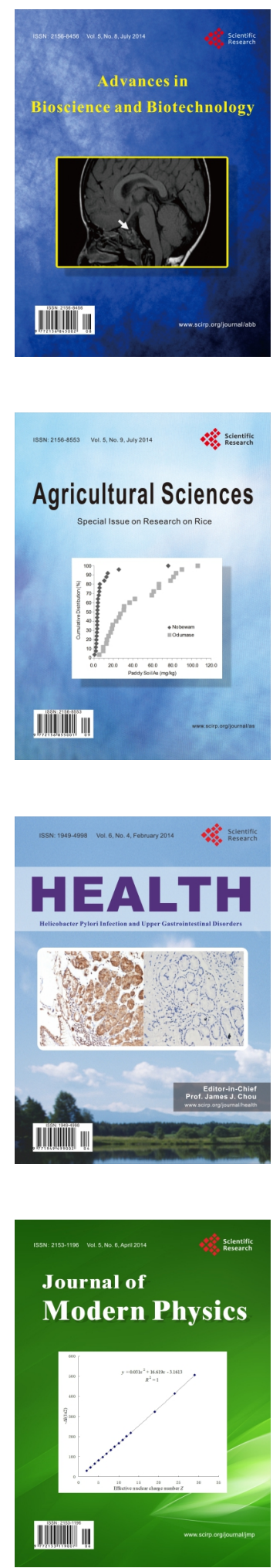
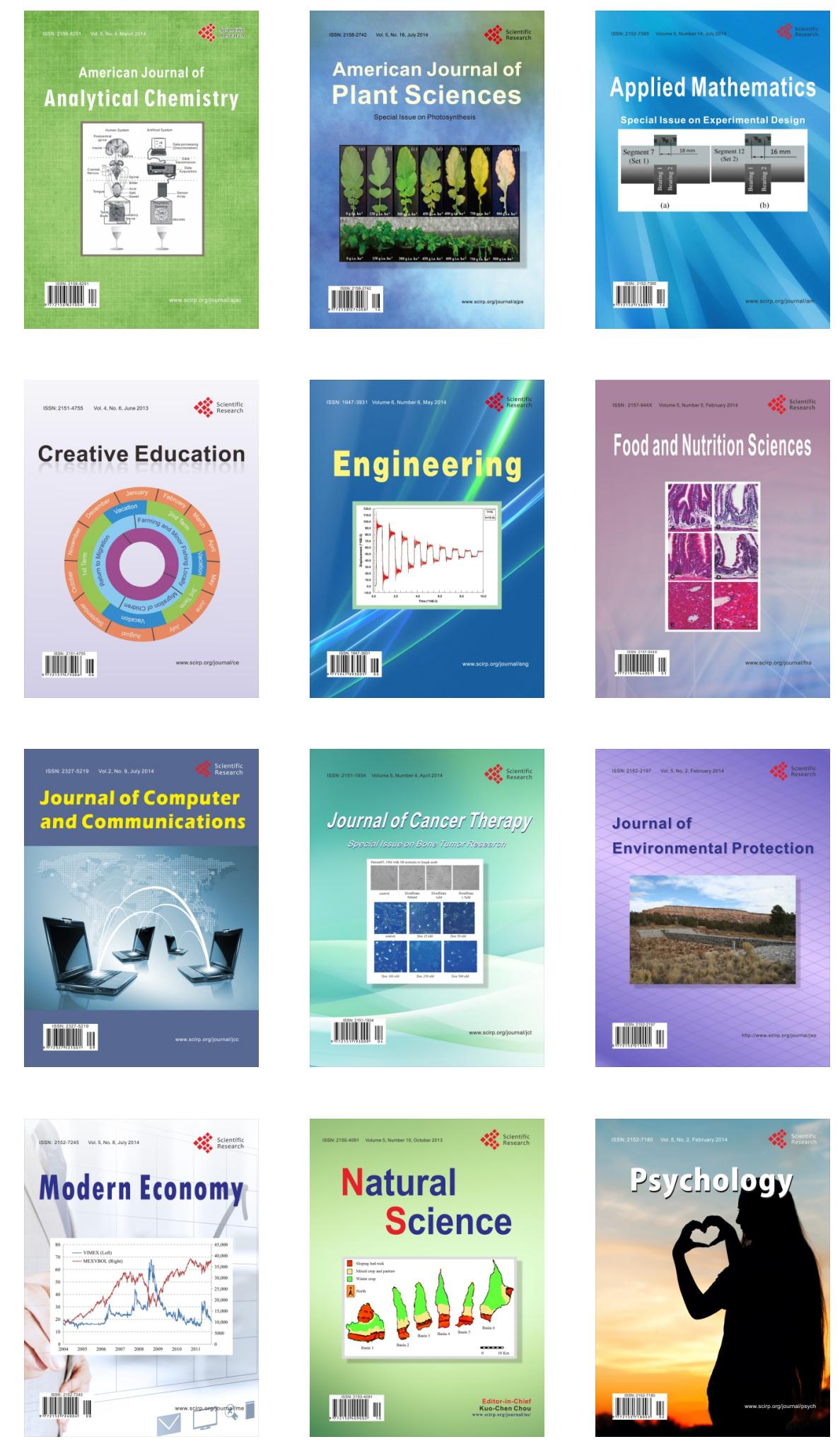